\title{
PhD Seminar within the framework of Water Doctoral Network of Engineering and Management
}

\author{
Semina dành cho nghiên cứu sinh trong khuôn khổ dụ án Mạng lưới nghiên cưu \\ sinh ngành Kỹ thuật và Quản lý
}

Event report

Kluska, Andreas ${ }^{1 *}$; Stefan, Catalin ${ }^{2}$

${ }^{I}$ IEEM - Institute of Environmental Engineering and Management at the University of Witten / Herdecke gGmbH, Alfred-Herrhausen-Str. 44, 58455 Witten, Germany; ${ }^{2}$ Institute of Waste Management and Contaminated Site Treatment, Technische Universität Dresden, Pratzschwitzer Str. 15, 01796 Pirna, Germany

\begin{abstract}
The Water Doctoral Network of Engineering and Management is a bilateral German - Vietnamese academic network with the aim to provide a platform for the development of joint research activities in water sector. Within the framework of the project, the network members organised a series of workshops and seminars targeted especially at $\mathrm{PhD}$ students from universities conducting research programs in water-related issues from both countries. The present paper summarises the outcomes of the last PhD seminar held on March 21-22, 2013 in Dresden, Germany. The seminar was attended by participants from IEEM - Institute of Environmental Engineering and Management at the University of Witten/Herdecke gGmbH and IAA - Institute of Waste Management and Contaminated Site Treatment at the Technische Universität Dresden.
\end{abstract}

\begin{abstract}
Mạng luới nghiên cúu sinh ngành Kỹ thuật và quản lý về nước là một mạng lưới hàn lâm song phưong Đúc-Việt, nhằm tạo ra một diễn đàn đẩy mạh hoạt động nghiên cứu hơp tác trong ngành nước. Trong khuôn khổ dụ án này, các thành viên thuộc mạng lưới đã cùng nhau tổ chức một loạt nhũng hội thảo và semina chủ yếu phục vu cho các nghiên cứu sinh của các truờng đại học đang tham gia cá chuơng trình nghiên cưu về nhũng đề tài liên quan đến nước ở cả Việt Nam và Đức. Bài báo quý vị đang đọc đưa ra tóm tắt ngắn gọn nhũng kết quả đạt được trong semina vìa tổ chức ngày 21.-22.03.2013 tại Dresden, Đức. Semina này huớng tới các đối tượng thuộc Viện Kỹ thuật và Quản lý môi truòng (IEEM) thuộc truòng Đại học Witten/Herdecke gGmbH và Viện Quản lý chất thải-Xủ lý vùng ô nhiếm (IAA) thuộc Đại học Tổng hợ Kỹ thuật Dresden.
\end{abstract}

Keywords: water, doctoral programme, engineering, management, $\mathrm{PhD}$

\section{Introduction}

The IEEM - Institute of Environmental Engineering and Management at the University of Witten/Herdecke $\mathrm{gGmbH}$ and the IAA - Institute of Waste Management and Contaminated Site Treatment at the Technische Universität Dresden (TUD) jointly organised a German Vietnamese PhD seminar on March 21-22, 2013 within the framework of the BMBF-funded project "Water Doctoral Network of Engineering and Management". The seminar took place in Pirna at the IAA facilities and included participants from both IEEM and IAA.

\section{Program}

The seminar was opened with a welcome address by Dr. Catalin Stefan (IAA) who introduced the activities of the institute in Vietnam. IAA conducts research and development projects in Vietnam since 1999 and has been involved in $19 \mathrm{R} \& \mathrm{D}$ projects in water and waste management, so far. The first educational program started in 1999 with the "Alumni cooperation project between Vietnam and Germany" (ALVIDE), continued with the "Follow-up mentoring of former students from developing countries" (ALUMNI) and it was concretized with the establishment of a joint Master Course on "Waste Management and Contaminated Site Treatment" in Hanoi and Dresden. On the research side, IAA contributed to a series of EU-funded projects on environmental management 
from 2003 - 2009 and initiated and coordinated studies on industrial and urban wastewater management, urban lake restoration and groundwater management. Over the past 14 years, more than 50 students graduated the DAADfunded joint Master Course between TUD and Hanoi University of Science (HUS) and $9 \mathrm{PhD}$ students wrote their PhD thesis on Vietnam-related topics. Since January 2010, IAA is supporting IEEM in the establishment and the implementation of the Water Doctoral Network of Engineering and Management.

On behalf of IEEM, Mr Andreas Kluska introduced the activities of the institute and emphasised the motivation for the initiation of the Water Doctoral Network. The network shall fulfil the requirements of a legally secured bilateral academic network of $\mathrm{PhD}$ students in the water technology and management sector. This shall lead to mutual recognition of admission requirements and graduation certificates, exchange of students and staff, a joint organisational structure and common regulations. In the long term, the network shall provide a solid basis for the development of joint research activities and therewith a fundament for sustainable academic and economic cooperation in the water sector. The first steps in achieving the project objectives consisted in signing a cooperation agreement between four partner institutions: IEEM and IAA on the German side, and Hanoi University of Science (HUS) and National Economic University (NEU), on the Vietnamese side. Based on their research profile, IAA and HUS will cover the technical and natural sciences while IEEM and NEU will contribute to economics and funding-related issues. It is expected that further universities from Germany and Vietnam will join the network later on.

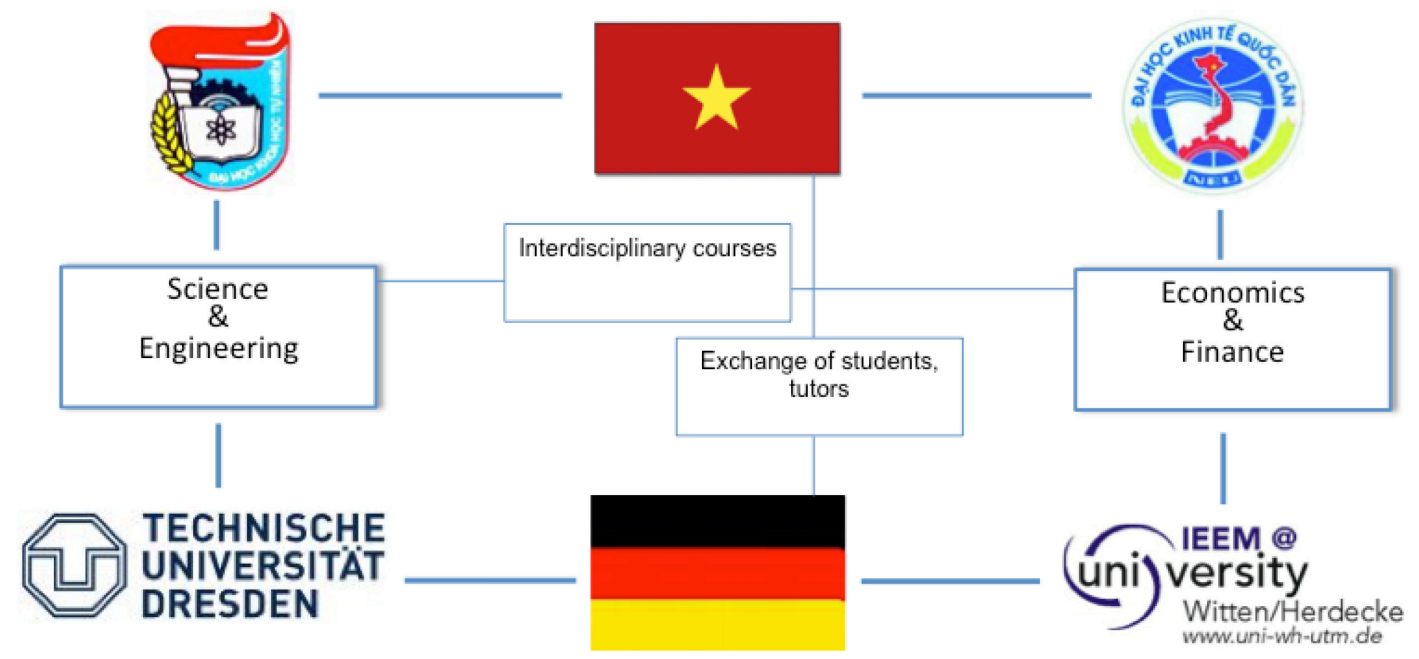

Figure 1. Planned structure of the Water Doctoral Network

Despite the high interest on all partners' side, the further development and the implementation of the Water Doctoral Network faces several constrains, such as:

- Very different curricula and admission requirements of the participating universities that cannot be changed on the mid-term perspective;

- Bureaucratic obstacles at both ministerial and university level;

- Legal and regulatory barriers.

Due to the reasons listed above, a way much bigger effort (financial and institutional) is necessary for the practical implementation of the project road map. The solution (merging the project into a bigger initiative, i.e. the proposed project Water Competence Centre Vietnam) was also not possible, yet due to stagnant approval procedures. Nevertheless, the Water Doctoral Network can bundle the research activities in German - Vietnamese cooperation programs at $\mathrm{PhD}$ level and therewith significantly contribute to a continuous experience exchange between the two countries.

After the keynote lecture of Mr Kluska, Ms Celia Hahn from IAA introduced the topic of her research in $\mathrm{Vi}$ etnam: "Material flow analysis of Arsenic in a craft village of Red River Delta, Vietnam". The presentation started with a general introduction to the occurrence and behaviour of Arsenic in the lithosphere, geosphere, atmosphere and biosphere, as well as general indications on the toxicity of Arsenic and its oxides and their bioavailability for plants and microorganisms. In case of Vietnam, Arsenic poses a serious threat to the inhabitants of the Red River Delta, one of the densest populated regions of the world. Ms Hahn further focused on the Dai Lam craft village in the River Delta and introduced the scope and objectives of the INHAND project ("Integrated Water Management Concept for Craft Villages with Example from Dai Lam, Vietnam"). The overall objective of the project is the improvement of the general conditions in the village (water, life quality and health conditions) by implementation of the following specific target activities: detailed inventory of production processes, means of production and wastewater streams, design and construction of an aerobic/anaerobic treatment facility and of an digestate treatment facility, generation of renewable energy (biogas), development of a concept for sustainable financing, rising the population awareness on environmental protection, and capacity development. Beside the project-specific coordination measures, Ms Hahn investigates the occurrence of Arsenic in the water streams of the village, waste and product streams and presented the results of the preliminary surveys in the village on the presence of Arsenic in groundwater, soil and several agricultural crops. 


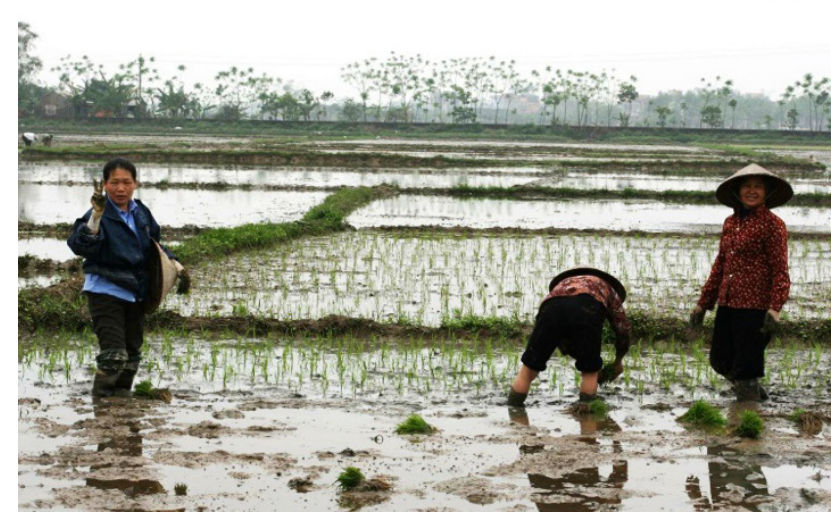

Figure 2. Rice crop cultivation in the Red River Delta

The next presentation was offered by Ms Hoang Mai Phan from IAA who introduced the topic "Capacity development in wastewater sector in Vietnam: actual needs and management approaches". The presenter, also a $\mathrm{PhD}$ student at IAA, summarised the main challenges in wastewater management in urban regions of Vietnam. This was the basis element for the initiation of a comprehensive survey on the demand for mutual educational and training programs. The target groups included executive staff from wastewater companies (engineers and managers), representatives of Ministry of Construction (MOC), staff of training institutions, and academic staff. The survey consisted in questionnaires, roundtable discussions and workshops, as well as individual interviews. The main outcomes were grouped in four categories: 1) personnel and organisation; 2) interdisciplinary technical aspects; 3) planning, construction, operation and maintenance of treatment plants; and 4) regulatory framework. The presenter also gave some examples on possible courses of action: vocational training adapted to real demand, development of strategies for sustainable implementation of advanced education, generation of technical standards and regulations. Further, Ms Phan gave three examples of bilateral initiatives where IAA brought significant contributions: the upcoming cooperation initiative between German Water Partnership (GWP) and Vietnam Water Supply and Sewerage Association (VWSA), the project on vocational education in cooperation with Deutsche Gesellschaft für Internationale Zusammenarbeit (GIZ), and the establishment of a Water Competence Centre in Vietnam.

\section{Discussion}

The discussion centred on the further development of the Water Doctoral Network and general Capacity Development events in bilateral German - Vietnamese research projects. Regarding the general positioning of WDN, the participants agreed that merging the WDN with a bigger initiative would be the best solution for the effective implementation. As previously discussed by representatives of IEEM, IAA and other actors involved, the WDN could be included in the 'Research and technology' component of the upcoming Water Competence Centre in Vietnam, for example. Unfortunately, the official start of this pro- ject will not be earlier than beginning of 2014, which is too late for a feasible connection of the two projects.

Nevertheless, a still very high demand in networking individual research activities was mutually identified so that WDN shall continue bridging scientific $\mathrm{PhD}$ research with existing capacity development activities. One first step of the network development is the realisation of a comprehensive human resources database as well as a $\mathrm{PhD}$ candidate portal. This will allow voluntarily registration of researchers as well as institutions with open $\mathrm{PhD}$ positions from both countries with listing of their scientific fields and contact details in order to match interested students with open PhD positions. This 'virtual network' can bring a significant contribution to the selection of most appropriate partners in future research projects and help addressing the right target groups in capacity development events. The network can be accessed at: https://www.researchgate.net/project/Water_Doctoral_Net work/. Another idea that could help to increase the visibility of bilateral programs is the joint publishing of research outcomes in open access journals. The newly launched Journal of Vietnamese Environment can be used as a suitable publishing platform since it accepts different types of manuscripts such as research articles, event reports, policy papers, review papers, short communications, as well as a dedicated section to academic abstracts of Master theses and $\mathrm{PhD}$ dissertations (more information about the journal and online submissions at: http://openaccess.tu-dresden.de/ojs/index.php/jve).

The next WDN event shall be another German - Vietnamese $\mathrm{PhD}$ Seminar but organised in Vietnam in order to facilitate the participation of Vietnamese researchers that could not attend previous seminars and meetings in Germany.

\section{Open questions}

- How to attract the participation of more $\mathrm{PhD}$ students in future events organised within the WDN network?

- What type of events is most suitable for implementation of WDN in Vietnam?

- How could the 'researchers index' and other virtual networks be realised and which source of funding is accessible?

- Is there any chance to include the WDN in a bigger project?

- How to assess the research quality at $\mathrm{PhD}$ level at Vietnamese universities?

- How to increase the publication rate of $\mathrm{PhD}$ students in German - Vietnamese research projects?

\section{Acknowledgement}

The seminar was organised with the financial support provided by the International Bureau of the German Federal Ministry of Education and Research, project no. 01DP12009. 